\title{
The influence of principals' managerial and school committee participation on the quality of education at elementary schools
}

\author{
Djafri Achmad ${ }^{1}$, Yasir Arafat ${ }^{2}$, Mulyadi Mulyadi ${ }^{3}$ \\ ${ }^{1}$ Sekolah Dasar Negeri 2 Tanjung Kerang, Indonesia \\ ${ }^{2}$ Universitas PGRI Palembang, Indonesia
}

\section{Article Info \\ Article history: \\ Received Jul 17 $7^{\text {th }}, 2021$ \\ Revised Aug 14 ${ }^{\text {th }}, 2021$ \\ Accepted Aug 30 ${ }^{\text {th }}, 2021$ \\ Keyword: \\ Principals' managerial School committee Quality of education}

\begin{abstract}
This study aimed to investigate: (1) the influence of principals' managerial on the quality of education; (2) the influence of committee participation on the quality of education; and (3) the influence of the principals' managerial and committee participation simultaneously on the quality of education. The data in this study were collected through distributing questionnaires to respondents. Them they were analyzed by using multiple regression analysis through $t$ test, $\mathrm{F}$ test, and determination coefficient test. The population in this study were all teachers at Elementary Schools of Babat Supat District which consisted of 294 teachers. The sampling technique used in this study was probability sampling with a sample size of 75 people. The results of the study showed that: (1) principals' managerial individually influences the quality of education at Elementary Schools of Babat Supat District; (2) participation of school committee individually influences the quality of education at Elementary Schools of Babat Supat District; (3) principals' managerial and school committee participation simultaneously influence the quality of education at Elementary Schools of Babat Supat District.
\end{abstract}

(C) 2021 The Authors. Published by IICET.

This is an open access article under the CC BY-NC-SA license (https://creativecommons.org/licenses/by-nc-sa/4.0

\section{Corresponding Author:}

Achmad, D.,

Sekolah Dasar Negeri 2 Tanjung Kerang, Indonesia

Email: jefriachmad72@gmail.com

\section{Introduction}

The urgency of improving the quality of education by looking at the growing reality conditions cannot be postponed any longer. Increasingly developing science requires that national education needs to internationalize quality so that it is in line with developments in science and technology in the world. Therefore, a quality management system is needed so that it can achieve the best performance [1].

Reality at this time contradicts what was expected. The quality of national education is still considered low. One of the main problems faced with the quality of education at this time is the low managerial ability of school principals [2] This confirms that the role of the principal as a manager in managing the school is considered a key factor in school success, including improving teacher performance. The back and forth of an organization's performance is determined by the manager.

The principal is the most important factor and supports the progress of an educational institution and determines the direction of policy in educational institutions. As the manager of an organization the principal regulates all matters relating to organizational life. As stated by [3], management is an activity to regulate 
various resources, both human and material, in order to carry out various activities of an organization to achieve optimal goals.

The consequence of the implementation of improving the quality of education requires adequate managerial management from the principal in managing schools and organizing educational human resources. The principal is one of the components of education that has the most role in planning and improving the quality of education. As the results of research conducted by [4], show that the principal as a manager plays a role in 1) planning the program by detailing the needs of educators and education personnel who will carry out tasks, planning the curriculum to be implemented, planning policies for adding guidance subjects two hours of counseling per week; 2) create an organizational structure that involves parents through the school committee and completes the required sarpras; 3) Providing a good and calm example at work, giving motivation and appreciation to personnel both morally and materially, increasing welfare, involving educators and education personnel in training and education and motivating senior teachers to have the spirit of life long education; and 4) supervising output, PBM, and students from the admission process to completion of school.

The principal should be able to understand, master and be able to carry out activities related to his duties as an education manager in order to carry out his duties properly. [5] stated that the role of the principal as a leader reflects the principal's responsibility to mobilize all resources in the school, so that a work ethic and high productivity are born in achieving its goals. Thus, the quality of education is highly dependent on the management of education which has a good plan, so that each implementation of these activities has clear objectives. In realizing educational goals, management is a very important factor. Therefore, in order for education to advance, it must be managed by professional education managers so as to realize the expected quality of education. [6] stated that quality schools are influenced by a quality education process with supporting factors, adequate facilities and infrastructure and costs, proper management, and a supportive environment.

Based on the above opinion, it can be explained that improving the quality of education in schools is greatly influenced by the leadership of the principal in regulating the course of education in schools. Effective principal leadership is able to foster a strong commitment to achieving educational goals in schools. The leadership of the principal who has a good performance, the effectiveness of the school he leads will be effective. On the other hand, the principal who has a poor performance, the effectiveness of the school he leads is less effective. In other words, school leadership is one of the determining factors in school effectiveness [7].

Four principles are the basis for translating the concept of School Based Quality Improvement Management in accordance with its objectives, namely autonomy, flexibility, participation, and initiative [8]. [9] argue that 1) autonomy is defined as independence, namely independence in regulating and taking care of itself, 2) flexibility is defined as the flexibility given to schools to manage, utilize, and empower school resources optimally to improve quality school, 3) participation is the creation of an open and democratic environment, and 4) initiative has a dynamic connotation and considers and treats people in schools as very important assets and has the potential to continue to be developed.

The discussion above can be concluded that in addition to the leadership role of the principal, community participation in the delivery of education is one of the principles in translating School Based Quality Improvement Management (MPMBS), in other words, community participation starting from decision making, education implementation and education evaluation is expected to be improve the quality of education. In line with the opinion of [10] which stated that the community will be the foundation for the improvement and quality of education services provided by schools, so that a harmonious relationship between schools and the community will have a significant impact on improving the quality of education.

[11] Argues that efforts to increase parental and community participation in school management and quality improvement are confirmed by including the Education Board and School / Madrasah Committee in the third part of article 56 of Law of the Republic of Indonesia No. 20 of 2003 concerning the National Education System.

Then it is supported by the opinion of [12] which stated that the school / madrasah committee as an independent institution plays a role in improving the quality of service both in providing consideration, direction, support for infrastructure, and education supervision at the educational unit level. Then the opinion of [13] stated that the School Committee is an independent body, does not have a hierarchical relationship with schools or other government institutions. [14] As school committees pay attention and build commitment with the community to support school programs aimed at improving the quality of schools, school committee also act as liaison partnerships between companies and government agencies with schools through field work practices and also building facilities and infrastructure to improve quality of education confirmed through a memorandum of understanding (MOU). 
The opinion above is in line with research conducted by [15] with the results of research which stated that school committees have a very important role to make a positive contribution to schools in Indonesia, both in empowerment efforts and Development of community participation in the world of education and in building education in educational units.

This research was conducted at all SD Negeri Babat Supat District. The researcher chose the research location as the research location because it was supported by several factors that were considered to support this research. These factors include, among other things, fairly complete facilities and sufficient resources to carry out this research. Seeing this condition, the researchers decided to carry out research in SD Negeri all Babat Supat District.

The results of preliminary observations made by researchers on January 2, 2020 to January 15, 2020, found that so far the indicators that the implementation of the principal's leadership was optimal in the process of education. However, researchers found that school principals had not paid attention and built commitment with teachers and teaching staff to support school programs that aim to improve the quality of education. This can be seen where the principal was less objective in carrying out teacher performance appraisals so that all teachers were given good grades so that there was no basis for teachers to improve their performance. In addition, the implementation of supervision of teacher performance by the principal had not been maximal, causing the supervisory and coaching functions that should have been carried out to improve teacher performance had not been effective; this also greatly affects the efforts to improve the quality of education in SD Negeri of Babat Supat District.

The results of preliminary observations made by researchers related to the role of the school committee in improving the quality of public elementary schools in Babat Supat District, the researcher put forward several indicators that stated the direct involvement of the school committee in the implementation of education in several public elementary schools throughout Babat Supat District. This could be seen where the school committee paid attention and built commitment with the community to support school programs aimed at improving the quality of SD Negeri in Babat Supat District.

However, there are several problems encountered by researchers, related to the role of school committees in SD Negeri in Babat Supat District, such as only some school committee administrators actively participate in monitoring PBM activities in schools, as well as in school committee plenary meetings held at schools. From the results of research conducted by [16] the strength of the committee comes from activeness, readiness to follow up on problems, clear division of labor, and good coordination; 2) forms of committee involvement, namely: holding meetings, raising funds, controlling finances, directing and involving parents in the program, reporting the results of activities to parents.

Based on the description that has been given above, this study aimed to determine the Influence of Managerial Principals and School Committee Participation on the Quality of Education at State Elementary Schools of Babat Supat District..

\section{Method}

The research method used in this research was quantitative descriptive method. Quantitative research is research that describes a problem whose results can be generalized [17]. This research method used the partial correlation method, partial correlation is used for analysis or hypothesis testing if the researcher intends to know the effect or relationship of the independent variable with the dependent, where one of the independent variables is controlled (made fixed) [18]. The population in this study were all teachers at SD Negeri of Babat Supat District which consisted of 294 teachers. The population in this study were as Table 1.

In sampling technique, the researcher used probability sampling techniques, namely sampling techniques that provide equal opportunities to each element (member) of the population to be selected as sample members [18] The determination of the number of samples was done by means of calculations by using the Slovin formula and obtained a sample size of 75 respondents.

Data collection techniques in this study were carried out through observation, documentation, and questionnaires. Data that had been provided by respondents in questionnaires that had been distributed, processed and used to provide an overview or explanation of the respondents' responses to each questionnaire item given through descriptive statistical tests and inferential statistics. The inferential statistics used were simple regression analysis and multiple regression analysis. Simple regression analysis techniques used in this study were the coefficient of determination (R2), partial test ( $\mathrm{t}$ test) and simultan test ( $\mathrm{F}$ test). The classical assumption tests carried out were normality, homogeinity, and linierity tests. 
Table $1<$ Research Population $>$

\begin{tabular}{|c|c|c|}
\hline No & Name of School & Amount of Teachers \\
\hline 1 & SD Negeri 1 Supat & 16 \\
\hline 2 & SD Negeri 2 Supat & 8 \\
\hline 3 & SD Negeri 3 Supat & 7 \\
\hline 4 & SD Negeri 4 Supat & 6 \\
\hline 5 & SD Negeri 1 Sukamaju & 10 \\
\hline 6 & SD Negeri 2 Sukamaju & 8 \\
\hline 7 & SD Negeri 3 Sukamaju & 6 \\
\hline 8 & SD Negeri 1 Letang & 11 \\
\hline 9 & SD Negeri 2 Letang & 9 \\
\hline 10 & SD Negeri 1 Banyuasin & 15 \\
\hline 11 & SD Negeri 2 Banyuasin & 9 \\
\hline 12 & SD Negeri 3 Banyuasin & 7 \\
\hline 13 & SD Negeri 4 Banyuasin & 9 \\
\hline 14 & SD Negeri 5 Banyuasin & 8 \\
\hline 15 & SD Negeri 6 Banyuasin & 7 \\
\hline 16 & SD Negeri 1 Gajah Mati & 10 \\
\hline 17 & SD Negeri 2 Gajah Mati & 8 \\
\hline 18 & SD Negeri 3 Gajah Mati & 8 \\
\hline 19 & SD Negeri 4 Gajah Mati & 8 \\
\hline 20 & SD Negeri 1 Langkap & 12 \\
\hline 21 & SD Negeri 2 Langkap & 8 \\
\hline 22 & SD Negeri 3 Langkap & 7 \\
\hline 23 & SD Negeri 1 Tanjung Kerang & 8 \\
\hline 24 & SD Negeri 2 Tanjung Kerang & 10 \\
\hline 25 & SD Negeri 3 Tanjung Kerang & 9 \\
\hline 26 & SD Negeri 4 Tanjung Kerang & 8 \\
\hline 27 & SD Negeri KM 108 & 8 \\
\hline 28 & SD Negeri Ramba & 9 \\
\hline 29 & SD Negeri Jantibun & 10 \\
\hline 30 & SD Negeri Tenggulang Jaya & 8 \\
\hline 31 & SD Negeri Bandar T & 9 \\
\hline 32 & SD Negeri Bedeng Genteng & 8 \\
\hline 33 & SD Negeri Sumber Jaya & 8 \\
\hline 34 & SD Negeri Tenggulang Baru & 7 \\
\hline 35 & SD Negeri 2 Ramba & 8 \\
\hline \multicolumn{2}{|c|}{ Total } & 294 \\
\hline
\end{tabular}

\section{Results and Discussions}

\section{Normality Test}

The purpose of the normality test is to determine the condition of the data obtained in a normal distribution or vice versa. The data normality test in this research was performed by using the Kolmogrof Smirnov Test (Z) technique.

Table $2<$ Normality Test Result $>$

\begin{tabular}{lcc} 
& \multicolumn{2}{l}{ Kolmogorov-Smirnov $^{\mathrm{a}}$} \\
& Sig. & \\
Quality of education & & $.200^{*}$ \\
Principal managerial & & .064 \\
School committee participation & & .055 \\
\hline
\end{tabular}

From Table 1, sig value for the principals' managerial variable was 0.64 ; sig value for school committee participation variable was 0.055 ; and the sig value for variable quality of education was 0.200 . All the sig values were greater than 0.05 , it can be concluded that the research variable data were normally distributed. 


\section{Homogeneity Test Results}

Table $3<$ Homogeneity Test Results $>$

\begin{tabular}{cccc}
\hline Levene Statistic & df1 & df2 & Sig. \\
2.208 & 1 & 76 & .141 \\
\hline
\end{tabular}

The results of Levene's test of homogeneity of variances showed that the significance value was $0.141 \geq$ 0.05 . so it can be concluded that the data were declared homogeneous.

\section{Linearity Test}

The results of the linearity test through the means options test for linearity obtained a significant value of deviation from linearity for the principals' managerial variable was 0.099 more than 0.05 and the significant value for linearity was less than 0.05 , meaning that there was a significant linear relationship between principals' managerial and the quality of education variables. The significant value of the deviation from linearity of the school committee participation variable was 0.480 more than 0.05 and the significant value of linearity was less than 0.05 , meaning that there was a significant linear relationship between the school committee participation variables with the quality of education.

\section{Hypothesis Testing Results}

The basis for the decision making for the $t$ test was to compare the calculated statistical value with the statistical table. If the t-count statistic $\leq$ the $\mathrm{t}$-table statistic, then Ho is accepted and vice versa if the t-count statistic $>$ the t-table statistic, then Ho is rejected.

1. The Influence of Principals' managerial Variables on the Quality of Education at SD Negeri of Babat Supat District

Ha: $p>0$

Ho: $\mathrm{p}=0$

H0: there was no positive and significant influence between principals' managerial on the quality of education.

Ha: there was a positive and significant influence between principals' managerial on the quality of education.

Table $4<$ Results of Partially Linear Regression Analysis of Variable X1 to Y>

\begin{tabular}{ccc}
\hline Model & $\mathbf{t}$ & Sig. \\
(Constant) & 3.129 & .003 \\
Principals' managerial & 11.042 & .000 \\
\hline
\end{tabular}

Table 4 shows that $\mathrm{t}$-count $=11.042$ and $\mathrm{t}$-table $=1.99300$; then $\mathrm{t}$-count $>\mathrm{t}$-table which meant Ho was rejected and $\mathrm{Ha}$ was accepted or it can be concluded that partially, there was a positive and significant influence between principals' managerial on education quality.

The results of this study indicate that Hypothesis H01 was rejected and Hypothesis Ha1 was accepted or in other words, the principals' managerial variables partially had an influence on the quality of education in SD Negeri of Babat Supat District. That was, if the managerial activity was carried out by the principal, which was measured based on the indicators of four managerial skills, namely: planning skills; resource organizing skills; skills to carry out activities; and control and evaluation skills improved, the quality of SD Negeri Of Babat Supat District would also increase and vice versa if the managerial quality of school principals decreased, the quality of education would also decline.

The results of the descriptive analysis also found that the majority of respondents agreed to the managerial variables carried out by the principal of SD Negeri of Babat Supat District. This shows that the managerial actions carried out by the principal of SD Negeri of Babat Supat District were in a very good category, in other words SD Negeri teachers of Babat Supat District gave very good responses about the managerial influence of the principal of SD Negeri of Babat Supat District. This was supported by the results of an interview with Mrs. Miftahul, S.Pd., one of the teachers at SD Negeri Babat Supat District (Interview, 12 November 2020), that the managerial activities carried out by the 
principal of SD Negeri of Babat Supat District were good, and the head schools had planning skills; resource organizing skills; skills to carry out activities; and excellent control and evaluation skills.

These results were also supported by observations of $10 \%$ of the research sample, where the researcher found that the managerial variables of SD Negeri of Babat Supat District principals showed an average level of implementation of up to $70 \%$. This shows that the research sample had fulfilled more than $70 \%$ of the observation indicators. This shows that the principals' managerial variable of SD Negeri Of Babat Supat District was good.

Based on the results of this study, the principal is the most important factor and supports the progress of an educational institution and determines the direction of policy in educational institutions. As the manager of an organization the principal regulates all matters relating to organizational life. As stated by Murniati and [19], management is an activity to regulate various resources, both human and material, in order to carry out various activities of an organization to achieve optimal goals.

The results of this study found that school principals' managerial is one of the factors that can affect the quality of education at SD Negeri Of Babat Supat District, so that the principal is expected to be able to carry out his managerial skills well. This is in accordance with the results of research conducted by [4] showing that the principal as a manager plays a role in 1) planning the program by detailing the needs of educators and education personnel who will carry out tasks, planning the curriculum to be implemented, planning policies for adding guidance subjects. two hours of counseling per week; 2) create an organizational structure that involves parents through the school committee and completes the required sarpras; 3 ) Providing a good and calm example at work, giving motivation and appreciation to personnel both morally and materially, increasing welfare, involving educators and education personnel in training and education and motivating senior teachers to have the spirit of life long education; and 4) supervising output, PBM, and students from the admission process to completion of school.

The results of this study support the results of the study conducted by [20] through the results of their study showing that there is a positive and significant influence on the leadership of school principals, education costs, school committees, school culture on the quality of the process; there is a positive and significant influence of principal leadership, school culture, process quality on the quality of graduates, there is no significant effect of the cost of education and school committee on the quality of graduates; Principal leadership, education costs, school committees and school culture have a significant effect on the quality of graduates through the quality of the process.

Based on the above discussion, it can be concluded that improving the quality of education in schools is strongly influenced by the leadership of the principal in regulating the course of education in schools. Effective principal leadership is able to foster a strong commitment to achieving educational goals in schools. The leadership of the principal who has a good performance, the effectiveness of the school he leads will be effective. On the other hand, the principal who has a poor performance, the effectiveness of the school he leads is less effective. In other words, school leadership is one of the determining factors in school effectiveness [7].

2. The Influence of School Committee Participation on Education Quality at SD Negeri of Babat Supat District

Ha: $\mathrm{p}>0$

Ho: $p=0$

H0: there was no positive and significant influence between compensation on teacher performance Ha: there was a positive and significant influence between compensation on teacher performance

Table 5. Results of Partially Linear Regression Analysis Variable X2 to Y

\begin{tabular}{|c|c|c|}
\hline Model & $\mathbf{t}$ & Sig. \\
\hline (Constant) & 6.122 & .000 \\
\hline committee participation & 3.681 & .000 \\
\hline
\end{tabular}

Based on Table 3, it was found that $\mathrm{t}$-count $=3.681$ and $\mathrm{t}$-table $=1.99300$, then $\mathrm{t}$-count $>\mathrm{t}$-table which meant that Ho was rejected and Ha was accepted. It can be concluded that partially, there was a positive and significant influence between school committee participation on the quality of education.

In this study, the results of the partial test ( $t$ test) of the school committee participation variable on education quality found that school committee participation had an influence on the quality of education and it could be said that the individual school committee participation variable had a significant influence on the quality of education with a sig value. was smaller than the probability value 
and t-count was greater than t-table. This also meant that, if the participation of the school committee had increased, the quality of education would also increase and vice versa if the participation of the school committee decreased, the quality of education would also decrease significantly. The results of the determination coefficient test in this study indicated that $15.7 \%$ of the quality of education at SD Negeri Babat Supat District could be explained by the participation of the school committee.

The results of the descriptive analysis also found that the overall average of respondents agreed to the participation variable of the Public Elementary School Committee in Babat Supat District. This shows that the participation of the Public Elementary School Committee of Babat Supat District was in a very good category. Thus more than $50 \%$ of respondents stated that they strongly agreed with the questionnaire statement on the variable participation of the SD Negeri School Committee at Babat Supat District that they received. These results are also supported by the results of observations on $10 \%$ of the study sample, where the researcher found that the participation variable of the SD Negeri School Committee of Babat Supat District showed an average level of implementation of up to $60 \%$. This shows that the research sample had fulfilled more than $60 \%$ of the observation indicators. This shows that the research variable of the participation of the School Committee at SD Negeri of Babat Supat District is quite good.

Based on the results of this study, in addition to the leadership role of school principals, community participation in the delivery of education is one of the principles in translating School Based Quality Improvement Management (SBQIM), in other words, community participation from decision making, education implementation and education evaluation is expected to improve quality of education. In line with the opinion of [10] which stated that the community will be the foundation for the improvement and quality of education services provided by schools, so that a harmonious relationship between schools and the community will have a significant impact on improving the quality of education.

The result of this study is also in line with [11] opinion that efforts to increase parental and community participation in school management and quality improvement are confirmed by including the Education Board and School / Madrasah Committee in the third part of article 56 of the Republic of Indonesia Law No. 2003 concerning the National Education System.

The results of this study also support the opinion of [12] which stated that the school / madrasah committee as an independent institution plays a role in improving the quality of service both in providing consideration, direction, support for infrastructure, and supervision of education at the educational unit level. Then the opinion of [13] stated that the School Committee is an independent body, does not have a hierarchical relationship with schools or other government institutions.

The result of this study is also in line with research conducted by [15] with the results of research which stated that school committees have a very important role in making a positive contribution to schools in Indonesia, both in empowerment and Development (development) of community participation in the world of education and in building education in educational units.

3. The Influence of Principals' managerial and School Committee Participation Simultaneously on Quality of Education at SD Negeri of Babat Supat District

Ha: $\rho>0$

Ho: $\rho=0$

H0: there was no positive and significant influence between principals managerial and participation of school committees simultaneously on the quality of education

Ha: there was a positive and significant influence between managerial principals and participation of school committees simultaneously on the quality of education

Table 6. Results of Multiple Linear Regression Analysis Simultaneously (F Test)

\begin{tabular}{lcc}
\hline Model & $\mathrm{F}$ & Sig. \\
Regression & 60.133 & $.000^{\mathrm{b}}$ \\
\hline
\end{tabular}

Based on Table 6 , it was found that F-count is 60,133 where F-count $>$ F-table $(60,133>3.12)$ which meant that Ha was accepted or there was a significant influence between the principals' managerial and participation of the school committee simultaneously on quality of education.

The simultaneous test results for the variable Principal and School Committee Participation on the Quality of Education at SD Negeri of Babat Supat District, it was known that the probability was much smaller than 0.05 and Fcount was greater than Ftable, so $\mathrm{H} 03$ was rejected and Ha3 was accepted or in other words, there was the influence of the principal and School Committee Participation 
simultaneously on the Quality of Education at SD Negeri of Babat Supat District so that it can be said that the variables of the Principal and School Committee Participation simultaneously had a significant influence on the Quality of Education at SD Negeri of Babat Supat District. This also shows that, if the principals' managerial and school committee participation in SD Negeri Babat Supat district increased, it would be followed by an increase in the quality of education and vice versa if the principals' managerial and school committee participation decreased, it would be followed by a decrease on the quality of education at SD Negeri of Babat Supat district significantly.

The coefficient of determination test results also found that $62.6 \%$ of the variable quality of education could be explained by the principals' managerial variables and school committee participation. Meanwhile, the remaining $37.4 \%$ was explained by other causes that were not examined in this study, such as working conditions, salary / compensation and others.

Based on the results of this study, it shows that the managerial role of the school principal and the role of the school committee as a manifestation of community participation in education greatly influences the governance of educational institutions. The managerial roles of school principals and school committees can have implications for ensuring the existence and sustainability of school institutions, with the existence of school committees the community can better assess and control the programs carried out by the school. Then the community will also be more concerned about and will be more supportive of school programs so that they are more beneficial to the community, including supporting sources of funds and the physical construction of schools. [21] stated that the role of school / madrasah committees is expected to improve the quality of education in schools, especially in the implementation of School Based Management (MBS). Improving the performance of the school committee can be pursued by optimizing the role of each member of the school committee, the involvement of all elements in the school committee organization and the distribution of tasks according to the capacity of personnel will be able to improve the performance of the school committee.

The results of this research are in line with the study conducted by [22] with the results of the research that the role of the school committee as a provider of consideration is manifested in the form of giving consideration to the provision and use of facilities and infrastructure needed by schools. The school committee also gives consideration to the use and utilization of budgets or funds obtained by schools, providing input on the draft school income and expenditure budget (RAPBS). Role as a controller by supervising budget allocations for the implementation of school programs and supervising school participation in school programs. The school committee also participates in the framework of transparency in the use of the allocation of education funds originating from the center so that it can be more accountable.

Based on the discussion above, it can be concluded that the principals' managerial and community participation are directly followed by community members through institutions such as school committees as independent institutions that are formed and play a role in improving the quality of educational services by providing consideration, direction and support for personnel, facilities and infrastructure. as well as education supervision. Both of these things can certainly support the creation of a more optimal quality of learning services and have an impact on increasing the achievement of student learning outcomes as educational output in schools. Thus, it can be concluded that educational organizations will be able to run well and smoothly in achieving educational goals if supported by the community. Community support through school committees has a major influence in efforts to improve the quality of education, because the school committee can provide input and control over the implementation of education in school institutions.

\section{Conclusions}

Based on the results of the research and discussion, it can be concluded as follows: 1) The principals' managerial had an influence on the quality of education at SD Negeri of Babat Supat District with a sig value lower than the probability value. 2) The participation of school committee had an influence on the quality of education at SD Negeri of Babat Supat District with a sig value lower than the probability value. Principals' managerial and school committee participation simultaneously had an influence on the quality of education at SD Negeri Babat Supat District with F-count greater than F-table and the significance level was lower than the probability value. 


\section{References}

Ansar. (2008). Empowerment of School Committees in Implementing School Based Management (SBM), Journal, Innovation, 5 (2), 1693-9034.

Cucu. (2014). Kontribusi Kepemimpinan Tranformasional Kepala Sekolah dan Kinerja Komite Sekolah terhadap Efektivitas Implementasi Manajemen Berbasis Sekolah di Sekolah Dasar Negeri SeKecamatan Ligung Kabupaten Majalengka. Tesis Administrasi Pendidikan UPI Bandung.

Depdiknas. (2011). Manajemen Peningkatan Mutu Berbasis Sekolah. Jakarta. Depdiknas

Garmawandi. (2012). The Role of School Committees in Supporting Education Funding Sources at the Primary and Secondary Education Unit Level, Journal of Education.

Hariwibowo, H. (2015). Evaluasi Peran Komite Sekolah dalam Meningkatkan Mutu Pendidikan. Jurnal Hasil Penelitian. 80-95.

Jayawinata, J. (2010). Standar-Kompetensi Guru Standar Kompetensi Kepala Sekolah Standar Kompetensi Pengawas Permendiknas No.12-13-dan-16. http://jahidinjayawinata61.wordpress.com/. Diakses pada tanggal 10 juni 2020.

Jannah, A. R., \& Kardoyo, K. (2020). Pengaruh Kepemimpinan Kepala Sekolah, Biaya Pendidikan, Komite Sekolah, Budaya Sekolah Terhadap Kinerja Sekolah. Business and Accounting Education Journal, 1(1), 1426.

Kriyantono, R. (2014). Teknik Praktis Riset Komunikasi. Jakarta: Prenadamedia Group.

Larasati, S, Y. (2009). Peran Komite Sekolah Dalam Meningkatkan Mutu Pendidikan Di SMA Ronggolawe Kota Semarang. Skripsi. Jurusan Hukum dan kewarganegaraan. Fakultas Ilmu Sosial. Universitas Negeri Semarang.

Machali, I dan Hidayat, A. (2017). The Handbook Of Education Manajement Teori dan Praktik Pengelolaan Sekolah/Madrasah di Indonesia. Jakarta : Prenada Media.

Makbulloh, D. (2011). Pendidikan Agama Islam. Jakarta: Raja Grafindo. Persada.

Murniati, AR, dan Usman, N. (2011) Implementasi Manajamen Strategi Dalam Pemberdayaan Sekolah Menengah Kejuruan. Bandung: Cita Pustaka Media Perintis.

Pahrudin. (2015). Peningkatan Kinerja dan Pengembangan Profesionalitas Guru Sebagai Upaya Peningkatan Mutu Pendidikan Di Indonesia. Proceedings from UNS : 978-602-8580-19-9

Rukanto, Y. A., \& Harapan, E. 2018. Effect Of Role School Committee And Operational School Assistance Fee (BOS) On The Quality Of Education In Senior High School. International Journal Of Scientific \& Technology Research Volume 7, Issue 9, September 2018.

Rosyadi, Y. I., \& Pardjono, P. (2015). Peran kepala sekolah sebagai manajer dalam meningkatkan mutu pendidikan di smp 1 cilawu garut. Jurnal Akuntabilitas Manajemen Pendidikan, 3(1), 124-133.

Sagala, S. (2013). Manajemen Strategik Dalam Peningkatan Mutu Pendidikan Pembuka Ruang Kreativitas, Inovasi dan Pemberdayaan Potensi Sekolah Dalam Sistem Otonomi Sekolah. Bandung: Alfabeta.

Septiana, D, N, Bafadal, I \& Kusumaningrum, D, E. (2018). Pelibatan Komite Sekolah Dalam Peningkatan Mutu Pendidikan. Jurnal Adminitrasi dan Manajemen Pendidikan Volume 1 Nomor 3 September 2018, : 293301.

Sukmadinata, N.S. (2010). Metode Penelitian Pendidikan. Bandung: Rosdakarya.

Sugiyono. (2012). Metode Penelitian Pendidikan Pendekatan Kuantitatif, kualitatif, dan R\&D. Bandung: Alfabeta.

Usman. (2011). Pengantar Statistika, Jakarta : Bumi Aksara.

Wahyuni, S., Fitria, H., \& Fitriani, Y. (2020). Implementasi Peran Manajerial Kepala Sekolah dalam Penyelenggaraan Pendidikan Anak Usia Dini. Jurnal Pendidikan Tambusai, 4(2), 1700-1705.

Zulkifli. (2015). Komite Sekolah Di Antara Cita dan Realita. Jurnal Potensia vol.14 Edisi 1. 99-127. 